\title{
Butler avec Agamben on the Spectrality of Love in a Post- Theoretical Culture
}

\author{
Jan Gresil S. Kahambing \\ Leyte Normal University, Tacloban City, Philippines, vince_jb7@hotmail.com, ORCID: \\ oooo-0002-4258-0563
}

\begin{abstract}
Cultural studies of recent memory tend to cling to love and find a certain answer from its musings. This critical move proceeds from various interrogations of cultural or cross-cultural practices towards adapting a linear progress so that love is tasked to provide an antidote to contemporary social maladies. This critical paper, however, attempts to appraise the idea that love is not a panacea, especially in a setting where theory is fragmented and assumes almost definitively a dead state. Instead, love functions as a specter that haunts a post-theoretical culture. The paper hinges this take from contemporary thinkers whom Nicholas Birns points to as "theorists without 'theory'." As such, the spectral concept of love is explored and critiqued in the lens of Judith Butler and Giorgio Agamben - both thinkers taken as separate and together - as a subversion to its affirmative theoretical standing and as a proposal on how its spectrality can inform the possibilities of its function.
\end{abstract}

Keywords: Love, Spectrality, Agamben, Butler, Culture, Theory

\section{Love in a Culture of Post-Theoria}

Cultural studies and references of recent memory tend to cling to love and find a certain answer from its musings. That love has, for instance, the power to undo the "spiritual malignancy" of hate and fear in the world (Williamson, 1992) is a pervading agenda that addresses the "generational problem" characterizing the "demonic chatter that life is lived" (Williamson, 2019). The enduring idea is that love, especially in Western cultures, has "received a predominantly positive press" where "in general, love in all its forms is perceived as a good" (Secomb, 2007, 75). That conclusive development is continuously asserted despite love's unrequitedness, imbalance, and colonial elements (recall de Beauvoir and Fanon). This critical move proceeds from various interrogations of cultural or cross-cultural practices towards adapting a linear progress so that love is tasked to provide an antidote to contemporary social maladies. The cultural perspective on love is in this sense "as much powerful as evolutionary heritage" (Karandashev, 2015, 15). The usual cultural referent points to the expression of love as bound within the rites and practices of marriage. Katz (2018) highlights the fact that for Hegel, marriage is a "typical

(C) AesthetixMS 2020. This Open Access article is published under a Creative Commons Attribution Non-Commercial 4.0 International License (http://creativecommons.org/licenses/by-nc/4.0/), which permits non-commercial re-use, distribution, and reproduction in any medium, provided the original work is properly cited. For citation use the DOI. For commercial re-use, please contact editor@rupkatha.com 
natural activity," which points to the "natural vitality" of love. For this invariable understanding, there is a certain objectivity in matters of compatibility that predominates over individual choice (McKenzie \& Dales, 2017). This allows for a cross-cultural aspect that pertains to love's universality in the human (Jankowiak, \& Fischer, 1992). What this means is that the bigger picture supplanting the varying yet unifying preconditions to love forms a theoretical standpoint that directs its movement. In Philosophy and Love: From Plato to Popular Culture (2007), Secomb maintains a certain thematic regard towards a theoretical backing of cultural, gender, and philosophical convergences to love: of "love as narrative, love's troubles and paradoxes, and an ethics and politics of erotics." In such cultural conjunctions, among others, there is an affirmative position despite the enduring paradoxes that may ensue concerning loving. As Secomb says, "the paradoxes of love do not, however, simply suggest that it harbors violent and damaging potentialities but also hints at the obverse - that love also founds human sociality through the connection and recognition, the caring and giving, it offers" (4). The theoretical construct of this endeavor grounds itself on culture to illustrate a pedagogical example from philosophy's "abstract conceptions." The thinkers that adhere to this are Levinas, Irigaray, Foucault, Derrida, and Nancy, to name a few. Thinkers who facilitate in love's musings are further categorized according to which kind they ruminate upon: Plato on Erotic Love, St. Paul's letter to the Corinthians and the New Testament interpretation of the Torah on Christian Love, Kant and Kierkegaard's Moral Love, Hobbes and Hegel's Love as Power, or Aristotle and Irigaray's Mutual Love (Wagoner, 1997).

However, Sbriglia, citing Birns, states that "whereas the 1970s saw the Yale School of deconstruction grow out of the work of Jacques Derrida, and the 1980s saw the New Historicism grow out of the work of Michel Foucault, from the 1990s onward" theory remains "broken up" $(2017,3) .{ }^{1}$ Theory in this sense becomes fragmented. It is then the concern of this paper to uncover that the so-called "theorists without "theory" in the likes of Judith Butler and Giorgio Agamben, among others' ${ }^{2}$, continues the task of thinking from the broken pieces of solid theoretical formations. There is a special link that ties the two, both as separate and together, in the short-circuiting of theory. And this does not exclude the dead theoretical underpinnings of love, so that love loses its grounding as a panacea able to provide positive conclusions for culture. In this setting, love starts to function, rather, as a specter, that is, of a "continuing love affair" which molds a "spectral metaphor:" a metaphor exemplifying "an absence, as chimera or amor impossibilia - a kind of love that, by definition, cannot exist" (Blanco \& Peeren, 2013, 312). What can be explicated here, for instance, is a spectrality of love which can be exemplified as a desire for the other:

If desire for - and of - the other is part of what is hidden in the crypt, part of what arrives or comes back as insistent and persistent phantom, then a spectral approach can make room for, or leave itself open to, the materialization and voicing of that desire so that it might thereby appear and speak. (Freccero, 2013, 343) 
The spectrality of love ruminates on this point of departure. Its spectralization is herein taken up as various haunting mechanisms in the thoughts of Butler and Agamben. Hence, it takes off from a standpoint where the linearity that goes with desire - achieving its object or desiring it straight to its core - is bound within impossible interventions, or turns that curtail or restrain desire itself and put it in a position of a metaxy or inbetween.

\section{Ghostly Doubts and Dispossessions: Butler on why Love is not the answer}

Judith Butler's concept of love becomes spectral and operates within a post-theoretical era in the assertion of doubt or doubting love. As she says in her essay on Klein: "doubt then marks the vacillation between love and hate; it is the epistemic effect of ambivalence" (Butler, 1998, 179). The point she pushes through, after admitting her position as a "secular Kierkegaardian" and taking her inspiration from Freud, is that "if one is doubting every lesser thing because one has doubted one's love, then that means one has lost an anchor of certainty, a firm epistemological ground" (Butler, 2002). And this position makes known the ubiquity of the haunting it imposes on everything: "if there is no greater thing than love, you will be compelled to doubt every other thing, which means that nothing, really nothing, will be undoubted by you" (54).

Doubting as a spectral mechanism at this point permits the experience of the uncanny (unheimlich). This experience is known in Freud as the feeling of strange repetition. Love, for Butler, fools us as we "find ourselves repeating older scenes in what appears as novel and unprecedented, find ourselves returned to older patterns of self after ecstatic outbursts of love" (55). The sense of repetition that subsists in the experience of loving jolts through skepsis, halts one's dealings and disturbs the linear progress of life events.

This is why the definition of love points to the unimaginable mishap that takes place upon envisioning its true nature because love no longer stands at a certain solid grounding. Love, she says, "is not a state, a feeling, a disposition, but an exchange, uneven, fraught with history, with ghosts, with longings that are more or less legible to those who try to see one another with their own faulty vision" (55; Italics mine). The spectral form of love creates a "scene of pure impossibility, of no actuality" and, like a ghost, "can open up a horizon that one previously took to be closed." It is precisely during this opening that the spectral lingers after something ended or is resistant to an ending that was already actualized. This is made possible by the Nietzschean inspiration that "what is lost, absent, or dead nevertheless becomes an object to conjure and sustain" (Bulter, 1998, 182).

Moreover, if love incites a ghostly disruption, doubting as well as strangely insisting, then love as a specter dispossesses as it possesses. That is to say, that the moment of being possessed by love is the very moment when spectrality operates, only that, in its function, it also robs at the same time the moment as it happens. What this 
means is that one who is in love works like a ghost "who falls then and there; who wants, who idealizes, who pursues; who cannot forget this or that kind of thing, wants it again, cannot stop wanting it easily; who wants to be pursued, or to become unforgettable, irreplaceable" (Bulter, 2002, 55).

And yet in confronting the social maladies that befall contemporary society, love will fail to provide a firm position. Bulter may well argue for a performativity of love as a viable language function. But even the performativity of love cannot give a clear solution to problems: even if "the relationship between language and power is part of power, and a very specific part of contemporary power" because resistance may also take a form of nonaction and by extension, the problem of language on the non-action of the performative (Bulter, 2017). The performative speech-act of love, for instance, in the utterance of "I love you" is a wager one makes and one becomes where the body becomes a "modality of love" (Butler, 2011). "To say 'I love you' is, through the strange logic of citationality and transitivity, to be located over here and there" (Bulter, 237). This strangeness in the logic of love goes in line with the uncanniness that governs the spectral. Both citationality and transitivity work on a state of dispossession. On the one hand, the citationality of love means that one risks of becoming anonymous since "to say 'I love you' is, of course, to submit to a cliché" (236). One can replace "I" and "you" anytime. On the other hand, the transitivity of love means that "the body is given and withdrawn at the moment in which we rely on language to convey our love to someone else. We are still over here, waiting, separated from that person" (237).

Finally, if there is a full form or spectrality in love that is its peak with deliriousness ${ }^{3}$, it can only lie within the performative of the political. That is to say, within the dispossessing act that can only be expressed fully in love's aporetic character. This further means that the expression of contemporary haunting lies within the notion of an aporia. ${ }^{4}$ Basing on the political character of dispossession, one is recast into spectral maneuvers by its two irresoluble opposing kinds.

On the one hand, relational dispossession functions "by virtue of some kind of contact with another, by virtue of being moved and even surprised or disconcerted by that encounter with alterity" (Butler \& Athanasiou, 2013, 3). It is a displacement that comes from the outside and yet troubles the inside. Love, which might be grounded on the peak of relationality in this sense, dispossesses and disturbs the very equilibrium of the self. The spectrality of love through relationality is an uncanny movement: "we do not simply move ourselves, but are ourselves moved by what is outside by us, by others, but also by whatever 'outside' resides in us" (3).

On the other hand, privative dispossession, which is derived from the sustainability of those powers over one's survival, further enforces the first one's haunting by supposing an original delirious spectrality: "every life is in this sense outside itself from the start, and its 'dispossession' in the forcible or privative sense can only be understood against that background" (3-4). In this sense, life can only be lived in the domain of the dispossessed. And this puts Bulter in the position of constantly interrogating whether or not there is ethical or political viability to work within this aporia. Here, love is caught in- 
5 | Butler avec Agamben on the Spectrality of Love in a Post-Theoretical Culture

between the opposing presences that may or may not be resolved unless it takes off from an originary spectralization, or in this case, an originary dispossession. As Butler says, "we can only be dispossessed because we are already dispossessed" (5).

What can such spectral life inform us towards love as a viable solution? Can this kind of love, which lingers in vacillations, be a surer entry point towards achieving compact forms of solidarities that can resist against contemporary cultural maladies? Bulter is amenable of "new forms of solidarities" that have been existing and must be pursued continuously. But for this to emerge again, such resistances cannot take the form of love at its core. As she says,

Will those solidarities be those we already know or would they take on another form? And through what political structure should we act? ... I, alone, do not have ready answers to these questions. I, working alone, cannot possibly answer those questions. The effective alliance forming now is one that is not exactly like those what we have already seen. Perhaps it's a moment to consider the unlikely allies, the police departments that refuse to deport. But let's be stopped and be disoriented by that. It doesn't mean we love them now or we're best friends. No, actually, I am not in favor of love as the basis of solidarity. Definitely not. (Butler, 2017; Italics mine)

In Frames of War, When is Life Grievable? (2009), Butler discusses that even in times of precariousness where reciprocal forms of sociability can be established, "these are not necessarily relations of love or even of care, but constitute obligations toward others, most of whom we cannot name and do not know" (14). Even when she supports assemblies in public demonstrations and protests with nonviolence, this does necessarily point to love. Nonviolence, she says, "is not about love, but about knowing what we do with our hatred" (Butler, 2018). One can cultivate rage, for instance, in educational means, peaceful resistance, and nonviolent forms of aggression, which can altogether link negotiations forming a larger cause for solidarities. And these may not engage further in friendliness or relations of love. The spectral character of love in this sense may continue to function within a state of dispossession. These may operate in elementary forms of doubting and advanced forms of aporia in an onto-political domain. But love cannot provide a clear rejoinder to the societal foreclosures that alienate one's possible relations. Because of the uncertainty and uncanny positionality of its spectrality, love is not the answer.

\section{Posthumous Pretense and Coming: Agamben's Incapable Love}

Giorgio Agamben works in a post-theoretical field through methods of interpretation where "you 'no longer have a floor under your feet" (Kishik, 2012, 99). As such, the form of life that functions afterward goes into an ethereal dimension where ghosts abound. In the exposition of "On the Uses and Disadvantages of Living Among Specters" in Nudities, Agamben contemplates his life in Venice like a dead language such as Latin. The idea is that although Latin can be read with the help of dictionaries and study guides containing conjugations and parsed tables for tenses, "it is still impossible, or nearly impossible, to 
find in this dead language the place of a subject, of the speaker who says 'I"' (Kishik, 13). This enabled him to label Venice as a "spectral city" colonized by ghosts. In a period laden with 'post' prefixes - postmodernism, post-structuralism, postcolonialism, posthumanism, and so on - the positioning condition points to a posthumous life, one that is not rooted but reactive of a previous state. It is in this sense that the contemporary world becomes a spectral world.

That people can still live after this fact of deadness means that they now assume a spectral life. But this condition has the disposition of pretense, that is, people at such point merely pretend that they are not living a dead state. What does spectrality mean for Agamben? He is quite straightforward in the explication that "spectrality is a form of life; a posthumous or complementary life that begins only when everything is finished" (Agamben, 2013, 475). Institutional variances at this point and the relations of individuals under this cannot hide the fact that, once this lens of the contemporary is uncovered, a spectral life will begin to ensue. The spectral turn of this understanding is that the relations that happen within individuals (herein understood by Agamben as power of life) morphs love into a specter. Love becomes a posthumous pretense precisely when it assumes the function of a dead language: though love is possible to be felt and lived as an experience, the subject of love cannot be placed with the "I".

In the political domain, love's spectrality in Agamben can succeed towards a pivoting of a coming politics. Meaning to say, that the potentiality of life after death may lie within Agamben's understanding of coming, which is an "absolutely unrepresentable community." The space where this community dwells is where, in his terms, a being that matters forms a 'whatever singularity' that is amabile or "lovable." Here, love, as a central concept in the coming community, "has little to do with psychological or emotional state, but rather constitutes an ontological mode, an ontological openness and relation to the world and its irreparability" (Salzani, 2011, 45). In this radical openness that constitutes an after-life, that is, an ontological mode after an irreparable one, there is a possibility of redemption.

However, the redemption that Agamben anticipates is not an answer: the coming does not guarantee a future in a sense of a linear solution to contemporary problems. This points again to the manner in which even redemption assumes a "spectral turn" when it disturbs linearity. As Salzani explains, "the 'coming' of the coming community is devoid of the tension towards something that lies ahead, in the future. It is devoid of a linear understanding of time which sees it as a cumulative progression" (46). As such, "coming does not mean future" according to Agamben $(1993,92)$. The coming politics is not an answer that makes things work in the sense of opera, but of a stop, a radical break, or as what Agamben says, "a peculiar sort of sabbatical vacation" (92).

In Agamben's discussion of 'Walter Benjamin and the Demonic: Happiness and Historical Redemption,' a spectral kind of love can be elucidated in the European iconographic tradition. Accordingly, the only figure that can bring together "purely angelic characteristics and the demonic trait of claws" is "not Satan but Eros, Love" (1999, 
141). Lying in a metaxy, love transcends even the boundary of the angelic and demonic. The same transcendence can be situated in the facticity of Heidegger's Dasein in Being and Time, which for Agamben is an opening that can only be represented in love.

For this spectrality to function, love, he says, "can no longer be conceived as it is commonly represented, that is, as a relation between a subject and an object or as a relation between two subjects. It must, instead, find its place and proper articulation in [...] transcendence" (187). In this sense, love becomes a passion of facticity, which allows for the emergence of an Ereignis, or event or 'coming into view.' What is vital in this logic of the coming that finds resemblance in the understanding of Agamben's coming is a delirious form of spectral love that lies in the very facticity of being.

Love is the passion of facticity in which man bears this nonbelonging and darkness, appropriating (adsuefacit) them while guarding them as such. Love is thus not, as the dialectic of desire suggests, the affirmation of the self in the negation of the loved object; it is, instead, the passion and exposition of facticity itself and of the irreducible impropriety of beings. [...] human beings are those who fall properly in love with the improper, who unique among living beings - are capable of their own incapacity. (204)

This kind of insisting love becomes spectral after acknowledging the end, that is, the moment of irreducibility, non-belongingness, impropriety, or incapacity. But this is because even after a dead state, love still subsists because its "original status" is mögen: “'to love' (lieben) is likened to mögen (which means both 'to want' and 'to be able')" in the context of potentiality-possibility (199). Delirious love is "the access to the knowledge of the incessant experience of belonging and 'nonbelonging' of Dasein, which is also the struggle between the 'I' and the 'other,' the subject and the object of love" (Bartolini, 2011, 128).

In going over Agamben's aesthetics and politics, one is confronted with a notion of potentiality, but this exists without theory or purpose. The fleeting or ungrounded mode of this continuing form of life projects a spectrality that represents limitations. Spectral love in this sense confronts its own limits. On the one hand, love assumes spectrality in the means of losing the actual subject. There is in Agamben a "poetic experience of love," which is "the physical entrance of the 'spirit' of love by the eye and through the eye." In this movement, love "penetrates the subject as an image of the beloved that, by turning into its spirit, bids farewell to the actual person" (Bartolini, 128). On the other hand, "today, when politics has become 'means without ends,' all we have is the world as so much potentially manipulable and manageable life; what we do not have is some idea or end as to what that potentiality might create" (Colebrook, 2008, 108). For Agamben, politics is "the sphere of pure means" (6o). What such a life entails is a spectral one, fleeting and traversing boundaries, awaiting further potential actualization.

\section{A Troubling (Con)Fusion as Conclusion, Or What does ghostly love want?}


The spectral turn contextualizes "the limits of representation and the impossibility of witnessing in/to an always-emergent and unfixable world" (cf. Dewsbury, 2003, as cited by Stevens \& Tolbert, 2018). There is a sense in which a world whose reliance on theory crumbles can only continue worlding (to use Heidegger's term) when it assumes a spectral function. A world of post-theory is a world of ghosts. What this means for Butler with Agamben is a world where doubts, dispossessions, pretenses, and incapacities abound. They make possible the freelance interrogations of contemporary agenda without coming into a position of lucid certainty - even the certainty of loving. Love is disjointed spectralized - in such a world and the manner of looking at it becomes disturbed by insistences that beget further insistences. With the caution of fleetingness, Kishik says that "doing philosophy without a solid textual ground may have a liberating effect, though it might very easily also result in free fall" (100). This fall is a "fall into the horrifying abyss of the zone of undecidability" (Kishik, 118). But does the ghostly form of love fall merely as a rumination on the standpoint of endless vacillations? Does this denote that in contemporary society, to proceed and go on with this cycle can only mean "buying a form of life" that "is as hopeless as buying love" (115)? But it is in fallenness that the spectrality of love functions. As Wolfreys (2008) explicates in Agamben's love, "love is just the memory of the originary fallenness of Being, of one finding oneself in the world" (156). Love's full spectrality in Agamben creates a fusion to the uncanny that is found in Butler: "Love is uncanny to the extent that it is the memory trace, the encrypted mnemotechnic of the very condition of Being in its facticity, its historicity" (156). In a world after theory, love is a "hauntological sign," a "phantasmatic character," and an "unrepresentable space" that begets an "empty place where each can move freely . . . where spatial proximity borders on opportune time" $(151,153,154)$. The special link that ties both Agamben and Butler together here is that love is detached even in the manner of doing philosophy, of hinging ideas to a certain theory. The spectral character of love provides subversion to its affirmative theoretical standing. How then can love's spectrality inform the possibilities of its function, or what does this ghostly love want? Certainly not the automatic resorting to solutions. What the fall incites is preliminary disorientation: Butler and Agamben's spectral love not only provides a break but also desires the very break that can provide an incongruous perspective of what lies ahead. However, even that desire itself cannot totally fulfill its function. On the contrary, it is not ultimate pessimism. There is an after-thought or an after-action that may possibly eradicate and offer remedies to the very specific problems that contemporary society now faces. A systemic problem needs an overhaul, but individual resistances also need it. Hence, it is becoming crucial, more than ever, to assess situations where a programmed platform and agendum for actions take on a thoughtless tendency. The transport from the subject to a non-subject is informed of the impasse with belonging and non-belonging but not an anarchic position where assemblies or a coming community cannot manifest. There are interventions in going over things in the lens of spectral love, but the very existence of this love itself already assures of potentialities. That love can exist after it dies, no matter that it is already devoid of its positive press is an indication of an impending momentary clarity. At present, Bulter cannot give such clarity in terms of a linear stand and Agamben speaks of a coming that is not linear as well. But that is just what the specter of love 
wants, a troubling confusion against the confident air that positively charges the hubris of relations between things. Together, the fusion of Butler with Agamben offers a space albeit empty - dispossessed or posthumous - where theory can still go on and love can still haunt.

\footnotetext{
Notes

${ }^{1}$ See for example Kahambing \& Duque (2019) for an explication of how a Žižekean critical reading of literature (in its case the Aladdin text) differs from other normative critical readings. The limitation, however, is the exclusion of some abstractive components of Žižek's reading through Hegelian idealism, Freudian desire, Marxist ideology, or Lacanian psychoanalysis.

${ }^{2}$ I am herewith excluding Alain Badiou and Slavoj Žižek who are also listed as part of the 'theorists without a theory' to limit the paper. This paper proceeds from understanding Butler and Agamben's thinking on love and its spectral element and then proceeds to coalesce the two. For a thorough explication of Badiou's amorous politics, moreover, see for example De Chavez (2016); on love in Badiou and Nancy, see De Chavez (2017). For some interpretations of love for Žižek, see Boerdam (2018), O’Dwyer (2010), Tutt (2012), and Wolfe (2010); on spectrality from Derrida and/to Žižek, see Kahambing (2019a).

${ }^{3}$ For an explication of Cheah's notion of delirious spectralization, see Kahambing (2019b).

${ }^{4}$ I expressed this aporetic foundation of friendship in contemporary philosophy, particularly in postmodern trends, as a call for a possibility of loving. See Kahambing (2015)
}

\section{References}

Abbott, M. (2011). Facticity. In Murray, A., \& Whyte, J. (Eds,), The Agamben Dictionary (p. 69). Edinburgh University Press.

Agamben, G. (1993). The Coming Community (M. Hardt, Trans.). Minneapolis: University of Minnesota Press.

Agamben, G. (1999). Potentialities (D. Heller-Roazen, Ed. \& Trans.). Stanford University Press.

Agamben, G. (200o). Means Without End: Notes on Politics (V. Binetti \& C. Casarino, Trans.). Minneapolis: University of Minnesota Press.

Agamben, G. (2011). Nudities (D. Kishik \& S. Pedatella, Trans.). Stanford University Press.

Agamben, A. (2013). On the Uses and Disadvantages of Living among Specters. In. Blanco, M, \& Peeren, E. (Eds.), The Spectralities Reader: Ghosts and Haunting in Contemporary Cultural Theory (pp. 473-477). Bloomsbury.

Bartolini, P. (2011). Love. In Murray, A., \& Whyte, J. (Eds,), The Agamben Dictionary (pp. 127-128). Edinburgh University Press. 
Blanco, M., \& Peeren, E. (2013). Spectral Subjectivities: Gender, Sexuality, Race/ Introduction. In. Blanco, M, \& Peeren, E. (Eds.), The Spectralities Reader: Ghosts and Haunting in Contemporary Cultural Theory (pp. 309-317). Bloomsbury.

Boerdam, C.M. (2018). A Love Beyond Belief: The Knight of Faith as Feminine, Revolutionary Subject. International Journal of Žižek Studies, 12(3), 22.

Butler, J. (2009). Frames of War. When is Life Grievable? London and New York: Verso.

Bulter, J. (2011). Response: Performative Reflections on Love and Commitment. Women's Studies Quarterly, $39(1 / 2), 236-239$.

Butler, J. (1998). Moral Sadism and Doubting One's Own Love: Kleinian Reflections on Melancholia. In L. Stonebridge \& J. Phillips (Eds.), Reading Melanie Klein (pp. 175-184). London and New York: Routledge.

Butler, J. (2002). Doubting Love. In J. Harmon (Ed.), Take My Advice: Letters to the Next Generation from People who Know a Thing or Two. New York: Simon \& Schuster. [Digital]

Butler, J. (2017). This is What Resistance Looks Like. UCLA Resistance Against Violence through Education (RAVE).

Butler, J. (2018). "Nonviolence is not about Love, but about Knowing What We Do with our Hatred." Conference at the Centre de Cultura Contemporania de Barcelona, Spain.

Butler, J. \& Athanasiou, A. (2013). Dispossession: The Performative in the Political. Cambridge, UK: Polity Press

Colebrook, C. (2008). Agamben: Aesthetics, Potentiality, and Life. The South Atlantic Quarterly, 107(1), 107120.

De Chavez, J. (2016). 'No theme requires more pure logic than love': On Badiou's Amorous Axiomatics. Kritike, $10(1)$, 269-285.

De Chavez, J. (2017). On the "Intimate Connivance" of Love and Thought. Eidos, http://dx.doi.org/10.14482/eidos.26.8737

Dewsbury, J-D. (2003). Witnessing Space: 'knowledge without contemplation'. Environment and Planning A, 35(11), 1907-1932.

Freccero, C. (2013). Queer Spectrality: Haunting the Past. In Blanco, M., \& Peeren, E. (Eds.), The Spectralities Reader: Ghosts and Haunting in Contemporary Cultural Theory (pp. 335-36o). Bloomsbury.

Jankowiak, W. R., \& Fischer, E. F. (1992). A Cross-Cultural Perspective on Romantic Love. Ethnology, 31(2), 149. doi: $10.2307 / 3773618$

Kahambing, J.G.S. (2015). The Cruelty of Loving in Philia and Amicitia. The Owl, 14, 102-107.

Kahambing, J.G.S. (2019a). Derrida and/to Žižek on the Spectral Victim of Human Rights in Anil's Ghost. International Journal of Žižek Studies, 13(3).

Kahambing, J.G.S. (2019b). Inhuman Rights: Components of Spectrality in Anil's Ghost. Rupkatha Journal on Interdisciplinary Studies in Humanities, 11(1), 71-79.

Kahambing, J.G.S., \& Duque, A.D. (2019). Aladdin as an Immoral Ethicist in Aladdin and the Magic Lamp. International Journal of Humanity Studies, 13(1), 84-95.

Karandashev, V. (2015). A Cultural Perspective on Romantic Love. Online Readings in Psychology and Culture, 5(4). https://doi.org/10.9707/2307-0919.1135 
Katz, G. (2018). "Love is only between living beings who are equal in power": On what is alive (and what is dead) in Hegel's account of marriage. European Journal of Philosophy, https://doi.org/10.1111/ejop.12423

Kishik, D. (2012). The Power of Life: Agamben and the Coming Politics (To Imagine a Form of Life, II). California: Stanford University Press.

McKenzie, L., \& Dales, L. (2017). Choosing love? Tensions and transformations of modern marriage in Married at First Sight. Continuum, 31(6), 857-867. doi: 10.108o/10304312.2017.1334873

Salzani, C. (2011). Coming Community. In Murray, A., \& Whyte, J. (Eds,), The Agamben Dictionary (pp. 4446). Edinburgh University Press.

O’Dwyer, K. (2010). Žižek on Love. Philosophy Now, 77.

Sbriglia, R. (2017). Introduction: Did Somebody Say Žižek and Literature? In R. Sbriglia (Ed.), Everything You Always Wanted to Know about Literature but Were Afraid to Ask Žižek (pp. 1-34). Durham and London: Duke University Press.

Secomb, L. (2007). Philosophy and Love: From Plato to Popular Culture. Edinburgh University Press.

Stevens, V., \& Tolbert, J. (2018). Beyond Metaphorical Spectrality: For New Paranormal Geographies. New Directions in Folklore, 16(1), 27-31.

Tutt, D. (2012). Radical Love and Žižek's Ethics of Singularity. International Journal of Žižek Studies, 6(2), 15.

Wagoner, R. (1997). The Meanings of Love. An Introduction to Philosophy of Love. London: Greenwood Publishing Group.

Williamson, M. (1992). A Return to Love. Reflections on the Principles of A Course in Miracles. HarperCollins.

Williamson, M. (2019). A Politics of Love: A Handbook for a New American Revolution. HarperCollins.

Wolfe, G. (2010). Love and Desire “Between Two Deaths”: Žižek avec An-sky. International Journal of Žižek Studies, 4(3), 22.

Wolfreys, J. (2008). Face to Face with Agamben; or, the Other in Love. In J. Clemens, N. Heron, \& A. Murray (Eds.), The Work of Giorgio Agamben. Law, Literature, Life (pp. 149-163). Edinburgh University Press. 